\title{
The Linguistic Behaviours of the Pupils of the Elementary Education and the Social Factors that Condition Them: Surveys of the Linguistic Behaviours of the Pupils of Elementary Education
}

\section{Gazmira Birce}

Director, “Dino Ismaili” School, Levan,Fier

\section{Esat Demo}

Lecturer

Doi: 10.1515/ajis-2017-0010

\begin{abstract}
The purpose of this study is to discover the way of speaking of pupils of elementary education, their linguistic behaviour, their speech, writing and speaking. The study aims to find the slinguistic factors that affect the pupils' way of speaking, but also to find the other factors such as social factors which affect or limit the student's speech. The participants in the study are the pupils of elementary school, particularly the pupils of fourth and fifth grades, to study their speech, the factors that affect it and if they speak according to the standard language. The study is conducted with the pupils of the fourth grade of "Dino Ismaili" school, because there is where we both work. We also conducted a conversation with the pupils to see their way of speaking and expression of thoughts. We also filled in some questionnaires in three schools of the city of Fier. The methods that we used are a combination of qualitative and quantitative methods, we used surveys and questionnires. The data of the study revealed that the factors that affect the speech are: age, gender, ethnic group, social background, family and two social factors such as social economic group and the parent's level of education. Other factors are book reading, TV and other children programs, conversation with peers and parents etc.
\end{abstract}

Keywords: pupils, elementary education, linguistic behaviour, non linguistic factors, linguistic inequality, communication, social environment.

\section{The Purpose of the Study}

The aim of the study is to highlight the linguistic behaviours and the social factors that affect the speech of the pupils, by surveying each aspect that affects the development of the linguistic competency and improvement of language skills.

\section{The Objectives of the Study}

This study aims to point out:

- The phenomenon of language inequality of the pupils of elementary school

- The linguistic behaviour of the elementary education children in the district of Fier

- The linguistic factors that affect this linguistic behaviour of these pupils

- The non linguistic factors that affect the linguistic behaviour of elementary education pupils

- The role of the family in their children's speech 


\section{The Questions of the Study}

How do the pupils of elementary education grades speak? How is their speech? Do they use the language standards? Does the economic factor affect the speech of these pupils? How is the way of peaking of the children who come from low economic level compared to the ones of a better economic level? Does the parent's level of education have an impact on the language of the elementary education pupils?

\section{The Hypotheses of the Study}

1. The non linguistic factors affect the pupils' speech

2. The social economic level of the parent's has an impact on the pupils' speech

3. The language of the children who come from the higher intelectual level is according to the language standards.

\section{The methods}

\subsection{Qualitative and quantitative}

The methods used in the study are probabilitative ones, the sample was randomly selected.

\subsection{The population and the sample}

The population taken into consideration: for the questionnaires: Schools "Naim Frasheri " fifth grade, "Andon Xoxa" fifth grade, "Pinellopi Pirro " fifth grade.

The sample: in the study participated 40 pupils, 10 from each grade of two schools and 20 from another school of the city of Fier, all of the students were randomly selected.

The procedure: After a careful review of the literature, we conducted the survey in the school where we work, afer that we filled in the questionnaires in the public schools of the city of Fier: "Naim Frasheri", 20 questionnaires, "Andon Xoxa" 10 questionnaires, "Pinellopi Pirro" 10 questionnaires.

The questionnaire itself contained 17 questions.

The survey was conducted in "Dino Ismaili" school, where I actually work as a director. After data collection, we worked on analyzing and concluding the results.

The purpose of the study was to collect the data on the last questions of the questionnaire. We analysed the data was using the program of exel, and the information was on given on percentages.

\section{Results}

\subsection{The questionnaire conducted for the elementary education pupils in some schools in Fier city}

\subsubsection{How many members are there in your family?}

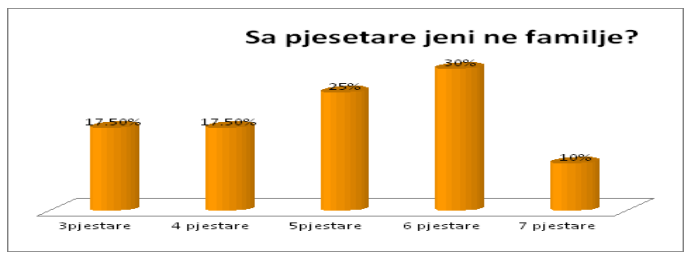

The graphic shows that $17.5 \%$ of the children have 3 members in the family, $17.5 \%$ with 4 members, $25 \%$ with 5 members, $30 \%$ with 6 members and $10 \%$ with 7 members. 


\subsubsection{Who do you live with?}

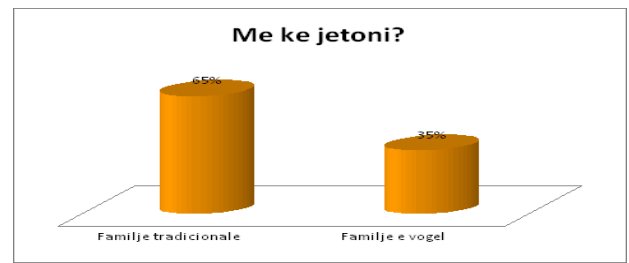

$65 \%$ of the pupils live in a traditional family, and $35 \%$ live in small families.

\subsubsection{What is the education level of your parents?}

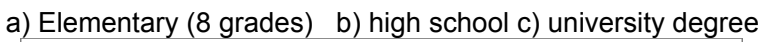

Çfarë arsimi kanë prindërit tuaj?

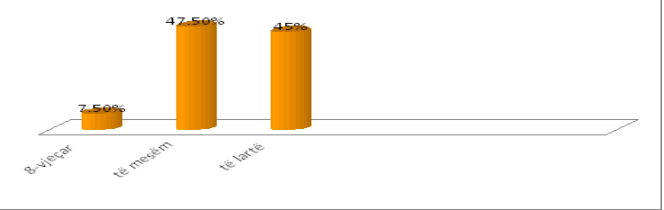

$7.5 \%$ of the pupils come from families with parents that have elementary education level (8 grades), $47.5 \%$ with high school education, and $45 \%$ with university degree.

\subsubsection{What is the profession of your parents?}

\begin{tabular}{|l|c|c|}
\hline Profession & Number of pupils & Percentage \\
\hline Homemaker & 12 & $30 \%$ \\
\hline Teacher & 14 & $35 \%$ \\
\hline Accountant & 5 & $12.5 \%$ \\
\hline Hairdresser & 6 & $15 \%$ \\
\hline Travel agency & 2 & $5 \%$ \\
\hline Cook & 2 & $5 \%$ \\
\hline Technician & 2 & $5 \%$ \\
\hline Waiter & 6 & $15 \%$ \\
\hline Driver & 2 & $5 \%$ \\
\hline Ranger & 5 & $12.5 \%$ \\
\hline Supplier & 3 & $7.5 \%$ \\
\hline Fisherman & 1 & $2.5 \%$ \\
\hline Cleaner & 1 & $2.5 \%$ \\
\hline Architect & 1 & $2.5 \%$ \\
\hline Secretary & 2 & $5 \%$ \\
\hline Medicine (nurse, medical doctor ) & 1 & $2.5 \%$ \\
\hline Laywer & 6 & $15 \%$ \\
\hline Engineer & 2 & $5 \%$ \\
\hline Director & 2 & $5 \%$ \\
\hline Businessman & 1 & $2.5 \%$ \\
\hline Manager & 1 & $2.5 \%$ \\
\hline Customs official & 1 & $2.5 \%$ \\
\hline
\end{tabular}


6.1.5 Have you attended kindergarten?
a) Yes
b) No

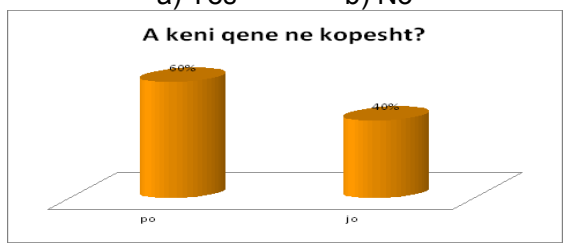

$60 \%$ of the children have attended kindergarten

\subsubsection{Do you read extracurricular books?}

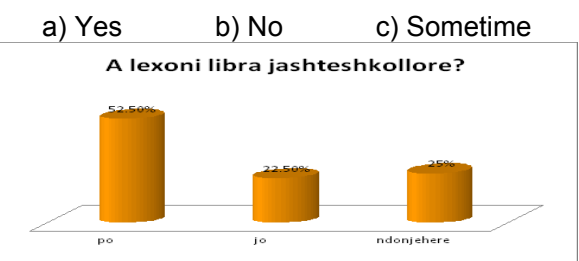

$52.5 \%$ of the pupils read extracurricular books, $22.5 \%$ do not read books and $25 \%$ sometime read books.

6.1.7 What kind of books do you like best?

a) romans b) fables c) novels d) poetry e) fairy tales f) scientific books

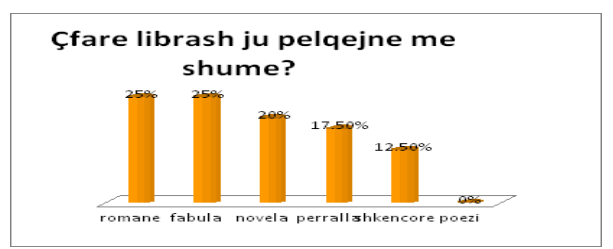

$25 \%$ like romans, $25 \%$ fables, $20 \%$ novels, përrallat $17.5 \%$ fairy tales, $12.5 \%$ science books and $0 \%$ poetry.

6.1.8 What is the subject that you like the best?

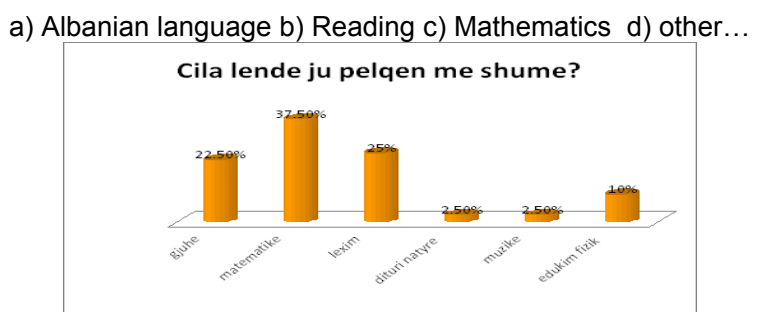

22.5\% like Albanian language, 37.5\% Mathematics, 25\% Reading, 2.5\% Nature Science, 2.5\% Music, 10\% Physical Education. 
6.1.9 When you do not understand information, question, or a word do your parents help?

a) Yes

b) No

c) Sometimes

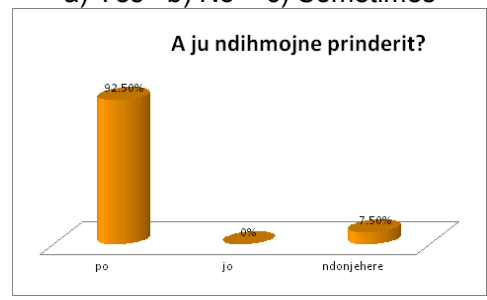

$92.5 \%$ state that parents help them while $7.5 \%$ sometimes, $0 \%$ do not get help.

6.1.10 If the parents help you, how are their answers? a) short b) long

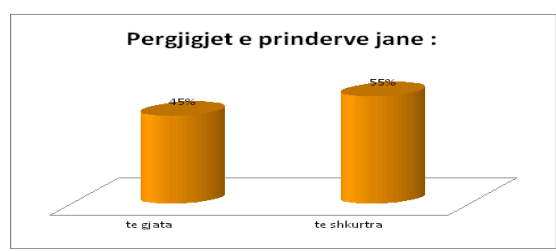

$45 \%$ of the answers are for long answers, $55 \%$ for short answers.

6.1.11 Does the teacher promote different themes for discussions?
a) Yes
b) No
c) Sometimes

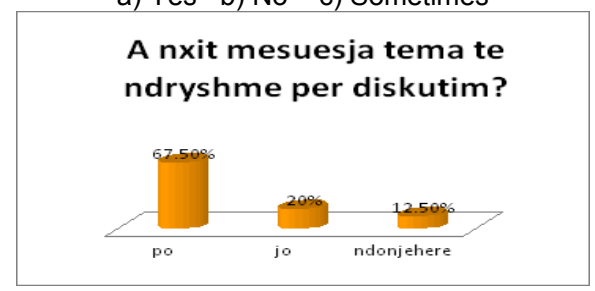

$67.5 \%$ answered yes and $20 \%$ no, $12.5 \%$ sometimes

6.1.12 Do you watch TV regularly?

a) Yes b) No c) Rarely

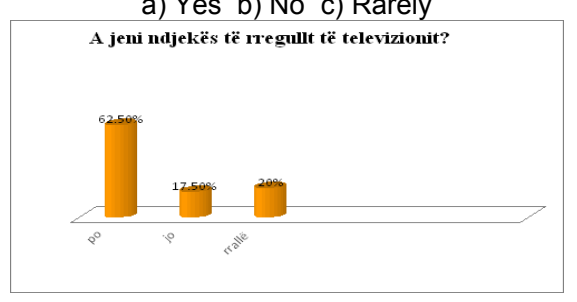

$62.5 \%$ watch TV regularly, $17.5 \%$ no and $20 \%$ rarely watch TV. 
6.1.13 Do you use internet regularly?

a) Yes b) No c) Sometimes

A jeni ndjekës të ragullt të internetit?

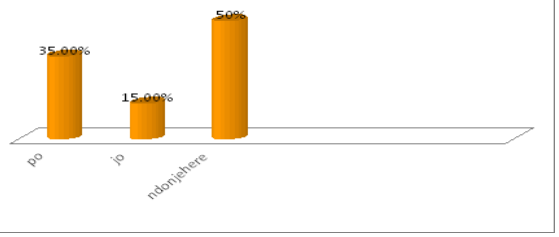

$35 \%$ use the internet regularly, $15 \%$ No, $50 \%$ sometimes

6.1.14 What do you like to do best when you are on the internet?

a) play b) read information c) communicate d) get information and communicate

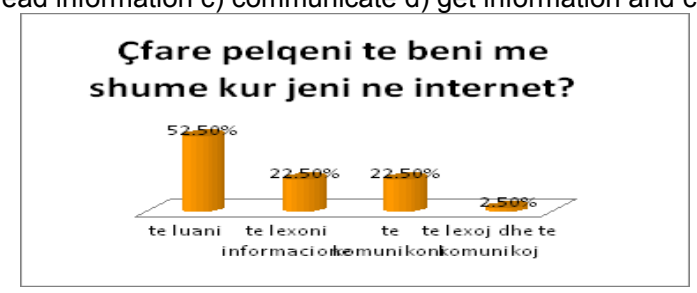

$52.5 \%$ like to play, $22.5 \%$ read information $22.5 \%$ communicate and $2.5 \%$ to get information and communicate

\subsubsection{Are you users of videogames?}

a) Yes b) No c) Sometimes

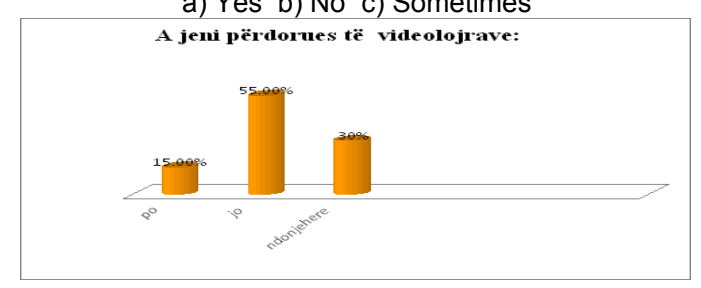

$15 \%$ play videogames, $55 \%$ No, $30 \%$ sometimes

6.1.16 How do you spend your free time?

a) reading books b) watching TV c) walking d) internet e) videogames

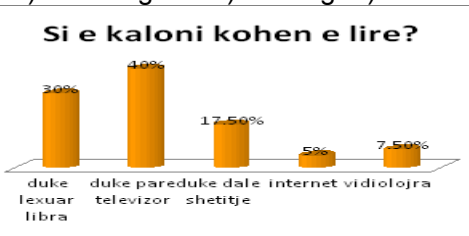

$30 \%$ of the pupils read books, $40 \%$ watch TV, $17.5 \%$ walking, $5 \%$ on internet, $7.5 \%$ play videogames. 
During the conduction of the questionnaires we noticed that a considerable part of the pupils lived in traditional families (mother, father, grandparents). Only a small part lived with close family (mother, father, siblings).

During the answering of the question "How many people are there in your family?" most of the pupils of "Dino Ismaili" School In Levan Fier, gave short answers, only a small part gave long, argumentative answers based on their age too. During the syrvey of the fourth grade pupils, we gave them an essay with the tittle

"How do you feel at the end of the school year?!"

Two of the most interesting essays of the "Penellopi Piro" School in Fier, were of one pupil whose parents were simple workers, and one whose parents were intellectuals.

The first essay of the pupil whose parents were intellectuals, here it goes:

The school vacations were over. I was so excited. I was one year older. I knew that this year the lessons were going to be harder and more complicated problems, but I knew I was going to be ok. I went to school together with my mother. We went to the school yard. I felt so enthusiastic, as I missed everything, friends, teachers, desks, the yard, the flowers. I ran to my friends and we hugged one another. Somewhere I noticed a smiley face, it was my teacher. I ran toward her and hugged her. The bell rang. How much I had missed it. We formed the line and went inside. The teacher wished us well. The school year was hard, but I managed to go through it with success. I learned a lot of things that I did not know before. We talked for many things. Slowly the days went by like the wind and the vacations came again. The end of the school was here, here went the fourth grade. Ready for the fifth. Oh, how I will miss friends, laughters, nice conversations. But I will miss my teacher too, the one who tought me how to solve hard problems. Now, my teacher I say to you:

Thank from the bottom of my heart my teacher. Thank you for the patience and for teaching me everything.

I love you very much.

The fisrt essay of the pupil whose parents were workers.

This year I was in fourth grade. The days were over, and the school ended. This year I learned a lot of things. I finished the fourth grade. The fourth grade was very difficult. The summer vacations came slowly. The sun shines and we start going to the beach. I can't wait to go out with friends, play and sunbathe. I will miss school and friends, but also my teacher, who is the best. Next year I will be in fifth grade and it is going to be very hard, but together with my teacher we will make it. But, the vacations will be over soon, and we will meet again next year. Have a very nice vacation my teacher.

One of the points that we discussed with the pupils of the fourth grade in the subject of Civil Education was the theme of "We are all equal". During the thme discussions, the problem was "Prejudging". Before explaining the concept, I asked the pupils the questions:

"Does anyone know how to explain what the word prejudging means"?

One of the pupils answers: To prejudge means to despise someone, to keep them away, as they can not be the same as us.

Then, I asked: "Should we prejudge people"? Why?

The answer was:

No, we should not prejudge, because we are all equal, regardless of race, skin color, religion, place of living.

Meanwhile I ask another pupil: -"Is it right to prejudge and why?"

The thing that was interesting is that this pupil had a hard time answering the question, and her answer is: 
No, we should not prejudge, because we are the same.

During the survey of the pupils' speech we noticed that the answers are really short and not well thought, but there are also pupils that reflect to the questions, and gave very good answers, so, eventhough the ethnic differences are noticeable in the speech, the standard language plays a very important role in language unification and elimination of linguistic behavior (Troplini 2011).

\section{Conclusions}

The aim of the study is to point out the way the pupils of elementary education cycle speak, and their speech. Also to find out the factors that send to linguistic prejudging, social factors that relate to the speech.

During the process of the study we noticed that:

- An important factor that affects the speech is the family environment where the children grow and develop. The mother or the father have an impact on the child speech. As a rule the child models the speech from the mother, since birth. Since the children in our study most of them are growing in traditional families, their speech is affected from the whole family, especially the grandparents. The children borrow from grandmother and grandfather the phrases and words they use in everyday life. Also, the answers given from mother or father, short ones, impact the way children speak. One of the children did not go to kindergarten and stayed home with grandmother, who did not let the child to go out and play with the friends. This child read books but still had difficulties in the flow of expressing the thoughts, and argumentation.

- Another factor that affects the children's speech is the economic factor. This happens because the parents in economic difficulties are more concerned about their problems and the child lacks their attention and devotion.

- Continuing with the factors, reading extracurricular books was very important in children speech. The children who read books (in Penellopi Piro School) presented more skills in expressing themselves than other children who stated that did not read any books.

- The education and intellectual level of the family showed to have an impact on children's speech, as manifested from the pupils of Penellopi Piro School where the pupils stated that their parents had university degrees. The children from the intellectual families were ready to discuss themes and arguments of different issues, and if they did not understand something, they demanded the word to be explained to them by using situations.

- The children who came from low level of social status had a different way of expressing themselves than the chidren from higher levels of society.

- TV was another factor which influenced the way the children speak. The chidren who saw different TV programs and documentaries had a better speech, a fluent logical explanations of their thoughts.

- A negative factor on pupils' speech was the overuse of internet and videogames. The kids who used the internet a lot did not have fluent explanation of their thoughts, short non argumented answers and did not read many books. The internet made them lazy.

\section{Recomandations}

- The child should attend kindergarten from the age of three, as they should be integrated into the society, to use the same language as their peers and not to use the phrases of the grandmothers or grandfathers which may not be appropriate for their age.

- Parents should read books to the children and with the children, since the small age.

- The parents should answer to the children with full sentences and not short sentences.

- The children should be in contact with their peers, have conversations, and not be kept inside.

- The teacher in school should use the standard language, far from foreigh language 
expressions, and slang language.

- The children should read as much as they could extracurricular books.

- The use of internet and videogames should be limited, as they make the children lazy.

\section{Refrences}

Giddens, A. "Sociologjia" ( 2007), Çabej, Tiranë

Hudson, A. R. "Sociolinguistika" (2002), Dituria, Tiranë

Musai, B ."Psikologji Edukimi" (1999) Pegi, Tiranë

Shkurtaj, Gj. "Sociolinguistikë e shqipes" (2009), Morava, Tiranë

Shkurtaj, GJ. Sociolinguistika, Tiranë 2003.

Troplini, E. Problematika "gjuhë dhe shtresë shoqërore" në Shqipëri, kumtesë e mbajtur në konferencën Ndërkombëtare të Fakultetit të Edukimit, pranë Universitetit "Aleksandër Moisiu", Durrës 2010

Troplini, E. Mësimnxënia e gjuhës shqipe në shkollat tona.(Disa probleme të planifikimit gjuhësor), kumtesë e mbajtur në konferencën e organizuar pranë Fakultetit Histori- Filologji, Tiranë 2010.....etj.

Troplini, E. Teoria e deficitit gjuhësor në kuadrin e kontakteve të sotme të shqipes, kumtesë e mbajtur në Seminarin e XXIX për Gjuhën, Letërsinë dhe Kulturën shqiptare, në Prishtinë, 2010.

Troplini, E. Roli $i$ standardit në unifikimin e gjuhës dhe rrafshimin e diferencave në sjelljen gjuhësore të individit, konference nderkombetare, Shkup, Tetor 2011.

http://mamimëndihmo.com/Edukim/GjuhaFolurShkrimi.html

http://ëëë.slideshare.net/cupidlucid/linguistic-and-social-inequality-presentation-710338

http://ëëë.shembulli.com/index.php?option=com_content\&vieë=article\&id=2325:funksionet-dhe-veçoritë-egjuhës\&catid=303:gjshqipe\&ltemid=672

http://linguasocio.blogspot.com/search?updated-min=2010-01-01T00:00:00\%2B01:00\&updated-max=2011-0101T00:00:00\%2B01:00\&max-results $=4$ 